Domingo Melfi.

\title{
PANORAMA UNIVERSAL
}

SOBRE ALGUNAS DECLARACIONES DE KEYSERLING

(1)REE Keyserling de Norte América que la mayor riqueza espiritual nacerá del fondo de una moral más libre. ¿Una moral más libre? Para muchos pensadores, la moral está ya en completa bancarrota y la ascensión continua del hombre hacia un plano de mayor cultura no logrará modificar gran cosa ese estado de delicuescencia. Se ha llegado a él después de transformaciones sucesivas, de crisis profundas de la sociedad, de nuevos métodos de vida.

Para muchos, para la mayoría quizá, la cuestión de la moral no es más que la mayor o menor libertad para desenvolverse o para definir la cuestión sexual. Las relaciones entre los individuos y los grupos se rigen por la violencia o la calma de los apetitos. Leyes, códigos, costumbres constituyen otras tantas trabas en el desarrollo formal de los individuos. Pero no bien el ser humano se encuentra frente por frente a sus instintos, retroceden las leyes, los códigos y las costumbres. 
En Estados Unidos existe un partido puritano que mueve guerra a los propugnadores de la moral libre. Pesquisa sus correrías y pretende ceñirlos en el marco de una severa corrección. No olvidemos que las religiones contienen en esencia una ética desolada. El budismo es el renunciamiento, el nirvana, y la vida el peor de los males según algunos libros sagrados. El catolicismo, la resignación, la pausa para el logro de un mundo mejor. Queda la vida presente, con sus teoremas inmediatos. Darles solución es o parece ser la norma a que hoy se ciñen los hombres de todo el mundo. Pero ¿cómo buscan los seres humanos esa solución?

La moral de la severidad, del cumplimiento de los deberes, ha perdido sus frenos o los tiene vencidos. La condición misma de la mujer nos da una norma. Está sin velos. Interiormente desnuda. En el exterior es la forma que corre a hundirse en el placer. Démosle un nombre cualquiera a ese placer. Será siempre la satisfacción de sus deseos más inmediatos: lujo, rique$z a$, amor. Para la melancolía o el dolor, hay antídotos comunes: el cocktail, el baile, la escapada maravillosa. En el fondo de todo, la necesidad de huir de sí misma, de escapar de las preocupaciones. ¿Y el pudor? Un sentimiento esclavo de la moda, de la temperatura, de la colectividad. Un barómetro va a darnos la cifra de esa temperatura que ciñe a la moral voluble: el balneario. Treinta años atrás, el «camisón» hasta la punta de los pies no permitía escándalos en las playas. De la carne femenina se ostentaban apenas las manos y el rostro. Cinco años más tarde mostraron las piernas hasta la rodilla. Cinco años después, surgían sobre el aire luminoso del mar, brazos, cuello y piernas. Los hombres saboreaban el goce secreto de contemplar a las mujeres en esa decoración movible y pérfida, junto a un oleaje que se deshacía sobre las riberas decoradas de ojos estupefactos.... Y algunos años más tarde la línea apenas interrumpida por el maillot de jersey que 
dibuja sin reticencia las curvas nerviosas. La mujer no esperaba la capa de baño que le tendía antes la amiga o la madre. Corría ahora, vibrante y gozosa, con toda la alegría de su cuerpo, desde la orilla a la caseta de vestirse, por entre los grupos, o los ojos hipócritamente frenéticos. A menudo corría por la arena y su cuerpo ardía en la luz húmeda del mar. Tendida más tarde al sol, sobre la arena, secaba su cuerpo en el que los granos menudos sobre el vello, brillaban al sol como un fino polvo de oro. Sus actitudes evocaban las de las primeras mujeres sobre el planeta. Libres y ávidas de deseos confusos. El pudor, la moral, vencidos. Con su largo camisón hasta los pies, muy cerca de la orilla, cogida de los cordeles de seguridad, se hundía en el agua y volvía a surgir, entre cortos gritos estridentes. La moral severa, taciturna.

El pudor elevado por las religiones de occidente a la categoría de un culto desciende, poco a poco, con la transformación vertiginosa de las costumbres, al nivel de una imagen pasajera. Había sido antes la reserva, el ocultamiento de las partes que no deben mostrarse. Ahora está sometido a la temperatura y a la moda. La belleza le ordena mostrarse. La conciencia de que hay una belleza digna de ser ostentada y contemplada. Pero esta conciencia se revela sólo cuando la moda la ha obligado a ser menos severa con el cuerpo humano desnudo que las religiones condenan a la obscuridad porque es el pecado, el deleite capitoso.

Con el progreso del maquinismo, de la industria, el pudor decrece. La moral, por tanto, se hace cada vez más libre, más rebelde. Deja de ser un teorema inflexible, un cuadro duro. Se convierte en una cosa liviana, dúctil, aérea. La moda, las costumbres, el pudor, la religión, imponían a la mujer las ropas interiores gruesas, ásperas, apretadas. Una evolución de la moda, de acuerdo con la mentalidad más libre, mudó aquellas ropas en telas diáfanas, sutiles, casi impalpa- 
bles. A despecho de la moral y de la religión. Los sacerdotes mismos fulminaron desde el púlpito a las damas que iban a los oficios divinos con ropas livianas, con los brazos desnudos, con el cuello libre de telas. Pero ellas no cedieron. ¿Podría ceder una mujer que quería ostentar su belleza, ante las amenazas de condenación? Así el pudor, en lucha contra fórmulas establecidas, contra principios seculares, deja de ser una cosa individual, para convertirse en un fenómeno colectivo. Fenómeno complejo, a pesar de todo, puesto que en determinadas circunstancias todo es posible, y en otras es todo lo contrario. En los bailes o en las comidas las espaldas se muestran desnudas. El hombre está a un paso. $\mathrm{Y}$ sin embargo....

Creemos que todo observador habrá notado la extraña libertad que preside en los balnearios en las relaciones de los sexos. Llegan como a un mundo diverso en el que no hay fronteras, ni leyes, ni códigos del honor. Todo es allí libre, nuevo, impreciso, confuso. El corazón deja de latir y cada uno lleva en su interior la dulce sospecha de una aventura que está por encima de todas las conveniencias y formulas que son habituales en las ciudades. La responsabilidad desaparece. Todo esto es un simple detalle en la sinfonía vasta de la descomposición de la moral.

Un ciudadano yanki le escribía a Keyserling para decirle que los hombres de negocios no se preocupan de la moral. En efecto, a un hombre de negocios no puede interesarle esa caja de sorpresas, que a menudo le dificulta en sus transacciones comerciales. Mientras exista la posibilidad de acaparar grandes sumas de dinero todos los caminos le parecerán perfectamente naturales. Al fin la moral acomodaticia de los negocios la aplicará, consciente o inconscientemente, en su vida privada y como nada influye más que el ejemplo en las relaciones entre los individuos, llegará un instante en que todos los frenos estén vencidos. 
En el amor, guerra al romántico. Lo fundamental es el sensualismo o la concurrencia económica. Hoy un marido engañado que adopta actitudes de matón parece un ser ridículo. Una mujer que salta sobre los prejuicios, para seguir el impulso biológico o de simple atracción, no sugiere ninguna de las reflexiones adustas de antes. La expresión "vivir la propia vida» ha cobrado una significación de singular independencia. Señalar a alguien como romántico es acusarlo de imaginativo, de soñador, de incapaz para adaptarse a las realidades inmediatas. Cuando un filósofo viajero como Keyserling cree que el hombre que reinará sobre el futuro será el chauffeur y luego en Estados Unidos afirma que una moral más libre surgirá del fondo de una mayor riqueza espiritual, se llega a pensar con un poco de ascmbro en esa multitud de chauffeurs materialistas que darán vida, gracias a la contradicción del filósofo, a una humanidad mejor.... Entre tanto, sólo la materia domina. Quizá si el filósofo tenga razón. El chauffeur ha modíficado la moral, la vieja moral al uso, moral de tradicionalismos y de fórmulas fijas.

Por lo demás, la violencia de la crisis económica ha dado un golpe de muerte a los más sólidos principios morales. Nada ha resistido a la presión del tanto por ciento, que en los países empobrecidos o sometidos a regímenes dictatoriales, es el triunfo del materialismo. La ausencia de ideales altos para concebir la vida o para gobernar, ha dado origen a una serie de transformaciones y reacciones de la sensibilidad, provocando la idea única del goce, como fin inmediato, y la indiferencia, como último juicio en los abusos y en las corrupciones. En sociedades materialistas a nadie sorprende el comportamiento de los hombres, porque lo primero que se averigua para justificar o analizar sus actos, es el estado de su cuenta bancaria.... El vértigo del lujo en la mujer, ¿no crea asimismo estados espe- 
ciales de indiferencia que le permiten comerciar con su cuerpo, para satisfacer sus deseos de ostentación? $¿ \mathrm{Ha}$ analizado alguien la tragedia que se encierra, a menudo, en la tibieza de un abrigo de pieles...? Si la vida que lievan la mayoría de los seres es puramente artificial, es imposible concebir una moral superiorno de esclavos ni de burgueses-que esté fuera de las miserias a que obliga el pesado materialismo de hoy. Materialismo cínico, disolvente, que no tolera la elevación, ni el idealismo, ni la dignidad. Para el materialismo imperante todos los seres son iguales. Todas las mujeres son fáciles. Todos los hombres, venales. Y la mujer misma que va a ofrecer su cuerpo en la calle, al mejor postor, mira con cierto desdén a la mujer de vida más limpia.

Los observadores de las realidades sociales-pesimistas casi todos-están de acuerdo, sin embargo, en - que la humanidad que atraviesa hoy el "negro túnel del materialismo» saldrá pronto de él para saborear la luz de un idealismo superior. Esperemos esa hora que nos libertará de las pesadas cadenas de la materia. 